\title{
Simulators for endoscopic retrograde cholangiopancreatography training: systematic review and meta-analysis
}

\author{
Saverio Tadeu de Noce Armellini'* (๑), Lucio Giovanni Battista Rossini' ${ }^{\circledR}$, \\ Eduardo Lelis Dias ${ }^{\top} \odot$, Marco Aurélio D'Assunção'
}

\section{INTRODUCTION}

Endoscopic retrograde cholangiopancreatography (ERCP) is a valuable technique for evaluating pancreatic and biliary ductal anatomy in a wide variety of clinical situations ${ }^{1}$. The first report of successful cannulation of the major duodenal papilla, which is the main stage of the procedure, was conducted in the United States in 1968 by McCune et al. ${ }^{2}$ The first endoscopic biliary sphincterotomies were reported almost simultaneously in 1974 by Kawai from Japan and Classen from Germany ${ }^{3}$. ERCP has evolved substantially: it has gone from a diagnostic procedure to a therapeutic tool thanks to technological innovations in endoscopes and accessories ${ }^{4}$. The learning process is long, and the main and essential step of the procedure is the cannulation of the major duodenal papilla 5 . ERCP can present severe complications (i.e., pancreatitis, hemorrhage, cholangitis, and perforation), especially in the hands of inexperienced endoscopists. The use of a simulator could be a valid tool for training and performing ERCP more effectively and safely ${ }^{6}$.

In this study, the systematic review and the meta-analysis were performed to clarify whether the use of simulators in ERCP training increases the cannulation rate of the duodenal papilla more than the traditional "master-student" teaching method.

\section{METHODS}

\section{Source of data and research}

This systematic review followed the recommendations of the Preferred Reporting Items for Systematic Reviews and Metaanalysis (PRISMA) ${ }^{7}$. No language or year of publication restrictions was applied. The following databases were searched: MEDLINE, EMBASE, CENTRAL, Web of Science, and
LILACS. The gray literature included ProQuest Dissertations $\&$ Theses Global and clinical trial records (clinicaltrials.gov). The date of the search was July 20,2020. The search used the following keywords combined with Boolean logical operators, appropriate for each database: "ERCP," "simulator(s),' 'training(s)," and "model(s)."

\section{Selection of studies}

Only randomized clinical trials (RCTs) were included in which the intervention group was trained with ERCP simulators before the practice of ERCP in supervised patients. The control group practiced ERCP directly on supervised patients ("master-student") without previous training on simulators. Two authors independently evaluated all studies identified by the survey using Review Management Website Covidence (http://www.covidence.org). A third review author resolved any disagreements.

\section{Data extraction and quality assessment}

Information on the study design, description of the participants, type of simulator ${ }^{8-11}$, type of training, description of the control group, and each outcome explored in the studies were extracted.

All included studies were evaluated for their methodological quality using the Cochrane Collaboration Risk of Bias tool $\left(\right.$ RevMan 5) ${ }^{12}$. The tool measures nine bias categories (i.e., selection, allocation, masking of data and statistical collectors, performance, detection, attrition, selective reporting of outcomes, and other biases). The items were scored as positive (low risk of bias), negative (high risk of bias), or insufficient information (uncertain risk of bias). The GRADE method was used to classify the level of evidence of the outcomes (i.e., high, moderate, low, and very low) using GRADEproGDT (https://gradepro.org/) ${ }^{13-17}$.

\footnotetext{
${ }^{1}$ Hospital Sírio-Libanês, Setor de Endoscopia - São Paulo (SP), Brazil.

*Corresponding author: sparmellini@uol.com.br

Conflicts of interest: the authors declare there is no conflicts of interest. Funding: none.

Received on April 06, 2021. Accepted on June 12, 2021.
} 


\section{Statistical analysis}

RevMan version 5.3 was used for the statistical analyses.

\section{RESULTS}

The search identified 3,310 studies. After duplicate studies were excluded, 2,386 studies were evaluated based on the title and abstract, of which 2,335 were excluded. Full-text studies were retrieved for 51 titles, of which 46 were excluded.
Four studies were included in the review ${ }^{18-21}$, although five publications were identified. It is noteworthy that two publications by Meng et al. ${ }^{21}$ and Meng et al. ${ }^{22}$ have the same method and same authors, and the beginning of the study of the 2019 publication ${ }^{21}$ was in $2016^{22}$, according to the information obtained at clinicaltrails.gov. We believed that one of the publications, Meng et al. ${ }^{22}$, served as a pilot study or initial publication and was incorporated into the publication referenced as Meng et al. ${ }^{21}$, so only the latter was enrolled in this review.

The findings of the studies ${ }^{18-21}$ are summarized in Table 1.

Table 1. Characteristics of the included studies.

\begin{tabular}{|c|c|c|c|c|}
\hline & Lim et al. ${ }^{18}$ & Liao et al..$^{19}$ & Hritz et al..$^{20}$ & Meng et al. ${ }^{21}$ \\
\hline $\begin{array}{l}\text { Type of } \\
\text { publication }\end{array}$ & $\begin{array}{c}\text { Article } \\
\text { Completed }\end{array}$ & $\begin{array}{c}\text { Article } \\
\text { Completed }\end{array}$ & Abstract & Abstract \\
\hline Centers & Multicenter & Multicenter & Multicenter & Not reported \\
\hline Location & USA & Taiwan & Hungary & China \\
\hline $\begin{array}{l}\text { Number of } \\
\text { participants }\end{array}$ & $\begin{array}{c}16 \text { (8 control, } 8 \\
\text { intervention) }\end{array}$ & $\begin{array}{c}16 \text { (8 control, } 8 \\
\text { intervention) }\end{array}$ & $\begin{array}{c}15 \text { (9 controls, } 6 \\
\text { intervention) }\end{array}$ & $\begin{array}{l}12 \text { (6 controls, } 6 \\
\text { intervention) }\end{array}$ \\
\hline $\begin{array}{l}\text { Characteristics of } \\
\text { participants }\end{array}$ & Maximum 30 ERCPs & $\begin{array}{l}\text { 1,000 EGDs done, } 0 \\
\text { ERCPs }\end{array}$ & $\begin{array}{c}\text { Experience in EGD, } 0 \\
\text { ERCPs }\end{array}$ & $\begin{array}{c}\text { No previous endoscopic } \\
\text { experience }\end{array}$ \\
\hline $\begin{array}{l}\text { Length of follow- } \\
\text { up after training }\end{array}$ & 16 weeks & 12 weeks & Not specified & Not reported \\
\hline Type of simulator & Mechanical (EMS) & Mechanical (EMS) & $\begin{array}{l}\text { Computational } \\
\text { (AccuTouch }^{\circledast} \text { ) }\end{array}$ & Mechanical (EMS) \\
\hline Number of ERCPs & $\begin{array}{l}265 \text { (139 intervention } \\
\text { and } 126 \text { control) }\end{array}$ & $\begin{array}{c}190 \text { (98 intervention and } \\
92 \text { control) }\end{array}$ & $\begin{array}{c}59 \text { (25 intervention and } \\
34 \text { control) }\end{array}$ & $\begin{array}{l}300 \text { (150 intervention } \\
\text { and } 150 \text { control) }\end{array}$ \\
\hline $\begin{array}{l}\text { Mean ERCPs per } \\
\text { student }\end{array}$ & $17 \pm 10$ & 11.875 & 3.93 & 25 \\
\hline $\begin{array}{l}\text { Description of } \\
\text { interventions }\end{array}$ & $\begin{array}{l}\text { Theoretical and simulator } \\
\text { training, repeated after } 8 \\
\text { weeks. In the ERCP, if in } \\
10 \text { min the trainee failed } \\
\text { after two attempts, he/ } \\
\text { she received manual help } \\
\text { from the supervisor }\end{array}$ & $\begin{array}{l}\text { Theoretical classes on } \\
\text { ERCP. The group in } 2008 \\
\text { received only one } 6-h \\
\text { practical class in the } \\
\text { simulator. In } 2009 \text {, the } \\
\text { group received biweekly } \\
\text { practical classes in the } \\
\text { simulator for } 12 \text { weeks. } \\
\text { In ERCP, unlimited verbal } \\
\text { instructions and manual } \\
\text { help after } 5 \text { min of } \\
\text { attempts. After a second } \\
\text { failure with manual help, } \\
\text { the supervisor took over }\end{array}$ & $\begin{array}{c}\text { Theoretical of } 2 \mathrm{~h} \text { and } \\
\text { training in the simulator. } \\
\text { There was no report on } \\
\text { the supervision of the } \\
\text { ERCP }\end{array}$ & $\begin{array}{l}\text { Training with verbal } \\
\text { instructions for } 20 \mathrm{~h} \text { in } \\
\text { the simulator. In ERCP, } \\
\text { verbal instructions and } \\
\text { manual help, if necessary. } \\
\text { If failure after } 20 \text { min of } \\
\text { attempts, the supervisor } \\
\text { took over }\end{array}$ \\
\hline $\begin{array}{l}\text { Description of the } \\
\text { group control }\end{array}$ & $\begin{array}{l}\text { Theoretical training } \\
\text { without training in the } \\
\text { simulator }\end{array}$ & $\begin{array}{c}\text { Theoretical classes on } \\
\text { ERCP only }\end{array}$ & $\begin{array}{c}\text { A 2-h seminar on ERCP, } \\
\text { without simulator } \\
\text { training }\end{array}$ & $\begin{array}{c}\text { Only training with verbal } \\
\text { instructions and manual } \\
\text { assistance, if necessary, } \\
\text { during ERCP }\end{array}$ \\
\hline Outcome main & Cannulation success rate & Cannulation success rate & $\begin{array}{l}\text { Note successful } \\
\text { cannulation }\end{array}$ & Cannulation success rate \\
\hline $\begin{array}{l}\text { Definition } \\
\text { of success in } \\
\text { cannulation }\end{array}$ & $\begin{array}{c}\text { Deep biliary cannulation } \\
\text { in } 10 \text { min of attempts } \\
\text { with fewer than three } \\
\text { manual aids from the } \\
\text { supervisor }\end{array}$ & $\begin{array}{l}\text { Deep biliary cannulation } \\
\text { with up to two manual } \\
\text { aids from the supervisor } \\
\text { for } 10 \mathrm{~min}\end{array}$ & Deep biliary cannulation & $\begin{array}{c}\text { Selective biliary } \\
\text { cannulation in } 20 \text { min }\end{array}$ \\
\hline
\end{tabular}

ERCP: Endoscopic retrograde cholangiopancreatography; Endoscopic retrograde cholangiopancreatography: mechanical simulator. 


\section{Methodological quality of the included studies}

Figure 1 shows the evaluation of the risk of bias of the four included studies ${ }^{18-21}$.

\section{Meta-analysis}

Using a meta-analysis with the random-effects model, a significant difference was found between ERCP simulator training

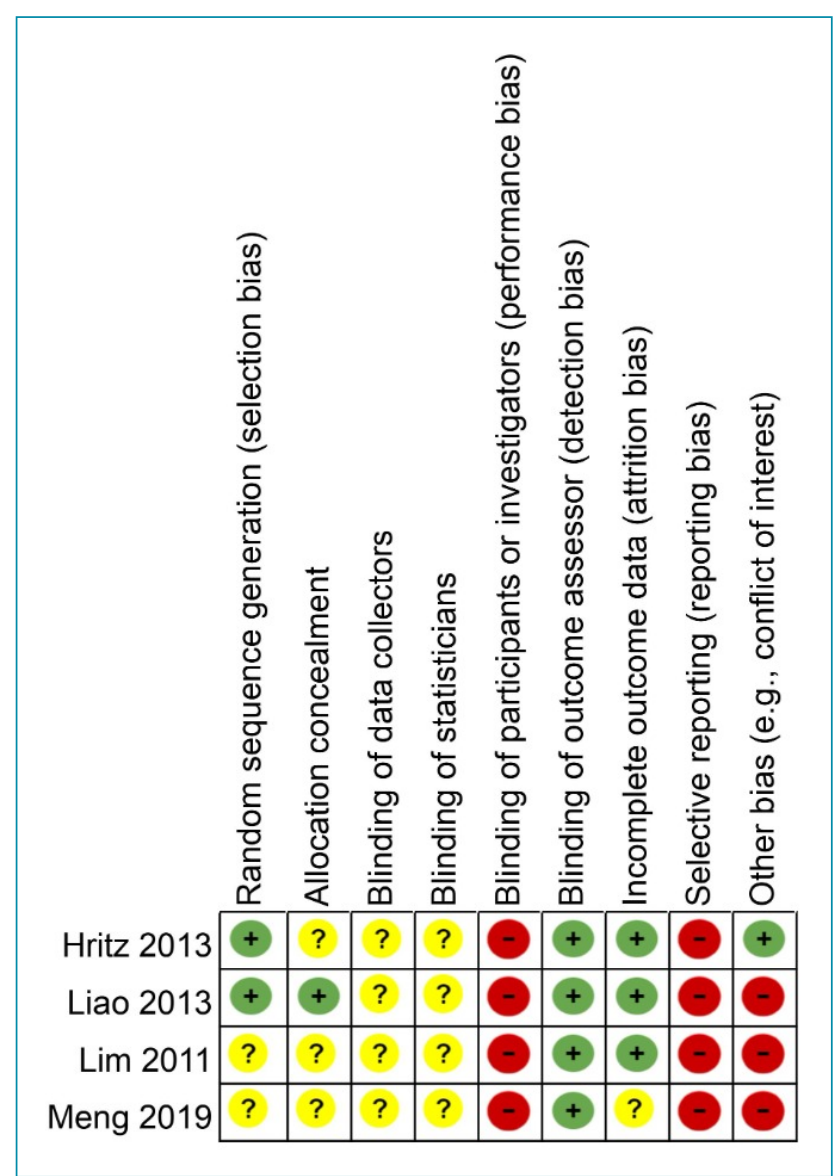

Figure 1. Summary of risk of bias of the included studies. and traditional teaching in the outcome cannulation success rate (three studies with sufficient data were included ${ }^{18,19,21}$ ). A relative risk of 1.40 (95\%CI 1.24-1.58) was found in favor of the simulator group (heterogeneity $\mathrm{I}^{2}=0 \%$ and $\mathrm{p}<0.00001$ ) (Figure 2).

\section{DISCUSSION}

No other systematic review on ERCP simulators was found in the literature.

Considering the data on the cannulation success rate of the three studies included in the meta-analysis ${ }^{18,19,21}$, there was a significant increase in the training group with simulators compared with the traditional teaching method. This result, which is favorable to the use of the simulator, may have obtained from the better knowledge of how to manipulate the endoscope (duodenoscope) and accessories for the ERCP before practice in patients ${ }^{23,24}$.

A systematic review by Ekkelenkamp et al. ${ }^{25}$ evaluated simulators for endoscopy in general. They found 14 studies related to students who were trained in ERCP simulators and cited an $\mathrm{RCT}^{18}$ without analyzing it. Considering the quality of the studies in this meta-analysis ${ }^{18-21}$, more full-text studies (not just abstracts) and improvements are needed to perform and describe randomization and allocation concealment. The masking of data collectors and statisticians was uncertain in all studies. Due to the nature of the intervention, masking of the participants was not possible.

A low risk of bias was identified regarding the blinding of outcome evaluators and the risk of incomplete results. The selective outcome report was considered high risk due to the absence of ERCP complication rates in patients. A high risk of bias from the conflict of interest was considered in three studies ${ }^{18,19,21}$, as one of the authors was the developer of the simulator used, a fact that could influence the study design.

Regarding the evaluation of the quality of the evidence for the success rate of cannulation using the GRADE system, it

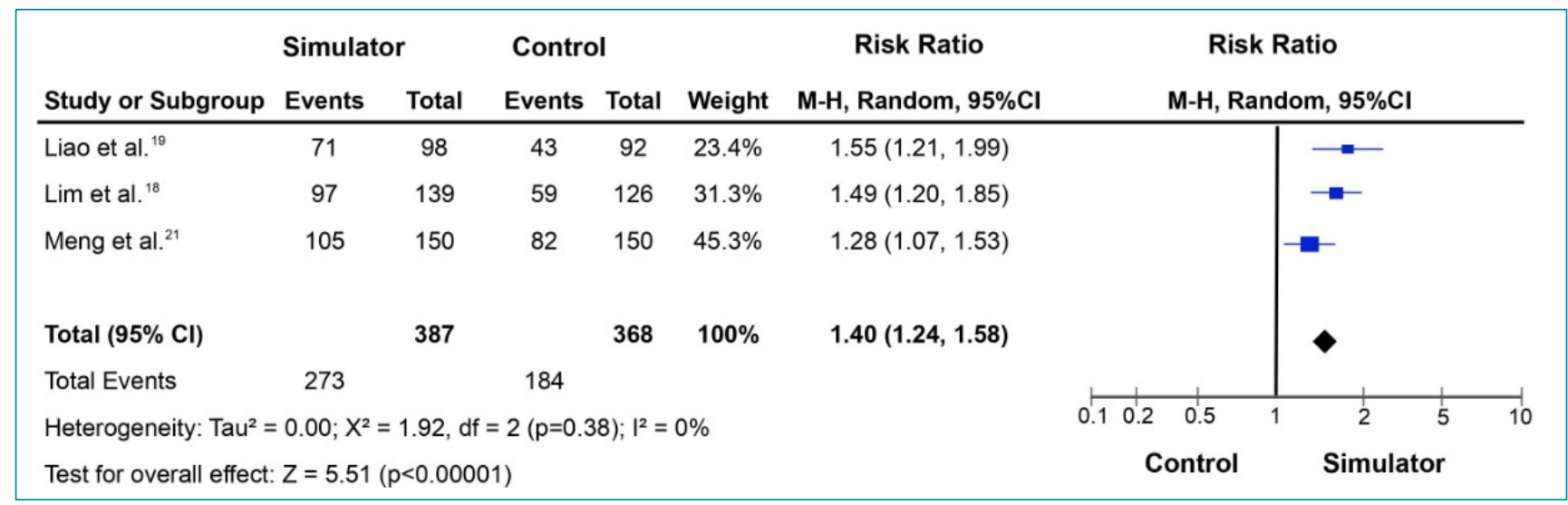

Figure 2. Meta-analysis of the outcome success rate at cannulation. 
can be concluded that our findings have moderate confidence, taking into account the risk of bias, inconsistency (heterogeneity), indirect evidence, imprecision, and publication bias ${ }^{26}$. The evidence found in this systematic review may be altered by new studies, modifying the confidence in the estimation of the effect, and may even modify the estimate ${ }^{26}$.

The limitations of this study are based on the small number of RCTs that met the selection criteria, which may have influenced the calculation of the results. The strategy to get around this limitation was a broad and exhaustive search so that no relevant RCTs were excluded.

\section{CONCLUSIONS}

Evidence of moderate confidence suggests that the training of physicians with ERCP simulators, when compared to the traditional teacher-student method, improves the success rate of cannulation of the greater duodenal papilla. Future studies may present such evidence in a more incisive and reliable way.

\section{AUTHORS" CONTRIBUTIONS}

STNA: Conceptualization, Data curation, Formal analysis, Funding acquisition, Investigation, Methodology, Project administration, Resources, Software, Supervision, Validation, Visualization, Writing - original draft, Writing - review \& editing. ELD: Data curation, Formal analysis, Investigation, Supervision, Visualization, Writing - original draft, Writing review \& editing. MAD: Formal analysis, Methodology, Resources, Supervision, Validation, Visualization, Writing review \& editing. LGBR: Supervision, Visualization, Validation.

\section{REFERENCES}

1. Falkenstein DB, Abrams RM, Kessler RE, Jones B, Johnson G, Zimmon DS. Endoscopic retrograde cholangiopancreatography in the dog: a model for training and research. Gastrointest Endosc. 1974;21(1):25-6. https://doi.org/10.1016/s0016-5107(74)73775-0

2. McCune WS, Shorb PE, Moscovitz H. Endoscopic cannulation of the ampulla of vater: a preliminary report. Ann Surg. 1968;167(5):752-6. https://doi.org/10.1097/00000658-196805000-00013

3. Baillie J. Biliary sphincterotomy: less benign than once thought? Curr Gastroenterol Rep. 1999;1(2):102-6. https:// doi.org/10.1007/s11894-996-0007-7

4. Baillie J. Endoscopic retrograde cholangiopancreatography simulation. Gastrointest Endosc Clin N Am. 2006;16(3):52942, viii. https://doi.org/10.1016/j.giec.2006.03.017

5. Leung JW, Yen D. ERCP training - the potential role of simulation practice. J Interv Gastroenterol. 2011;1(1):14-8. https://doi.org/10.4161/jig.1.1.14594

6. Leung J, Lim B, Ngo C, Lao WC, Wing LY, Hung I, et al. Headto-head comparison of practice with endoscopic retrograde cholangiopancreatography computer and mechanical simulators by experienced endoscopists and trainees. Dig Endosc. 2012;24(3):17581. https://doi.org/10.1111/j.1443-1661.2011.01209.x

7. Moher D, Liberati A, Tetzlaff J, Altman DG, PRISMA Group. Preferred reporting items for systematic reviews and metaanalyses: the PRISMA statement. PLoS Med. 2009;6(7):e1000097. https://doi.org/10.1371/journal.pmed.1000097

8. Itoi T, Gotoda T, Baron TH, Sofuni A, Itokawa F, Tsuji S, et al. Creation of simulated papillae for endoscopic sphincterotomy and papillectomy training by using in vivo and ex vivo pig model (with videos). Gastrointest Endosc. 2013;77(5):793800. https://doi.org/10.1016/j.gie.2012.12.015

9. Neumann M, Mayer G, Ell C, Felzmann T, Reingruber B, Horbach $\mathrm{T}$, et al. The Erlangen Endo-Trainer: life-like simulation for diagnostic and interventional endoscopic retrograde cholangiography. Endoscopy. 2000;32(11):906-10. https:// doi.org/10.1055/s-2000-8090
10. Leung JW, Lee JG, Rojany M, Wilson R, Leung FW. Development of a novel ERCP mechanical simulator. Gastrointest Endosc. 2007;65(7):1056-62. https://doi.org/10.1016/j.gie.2006.11.018

11. Bittner 4th JG, Mellinger JD, Imam T, Schade RR, Macfadyen $\mathrm{Jr}$ BV. Face and construct validity of a computer-based virtual reality simulator for ERCP. Gastrointest Endosc. 2010;71(2):35764. https://doi.org/10.1016/j.gie.2009.08.033

12. Higgins JPT, Altman DG. Chapter 8: Assessing risk of bias in included studies. In: Higgins JPT, Green S, eds. Cochrane Handbook for Systematic Reviews of Interventions. Version 5.1.0 [updated March 2011]. Available from: https://handbook-5-1. cochrane.org/chapter_8/8_assessing_risk_of_bias_in_included_ studies.htm

13. Guyatt GH, Oxman AD, Vist GE, Kunz R, Falck-Ytter $Y$, Alonso-Coello $P$, et al. GRADE: an emerging consensus on rating quality of evidence and strength of recommendations. BMJ. 2008;336(7650):924-6. https://doi.org/10.1136/ bmj.39489.470347.AD

14. Guyatt GH, Oxman AD, Vist G, Kunz R, Brozek J, AlonsoCoello $P$, et al. GRADE guidelines: 4. Rating the quality of evidence -- study limitations (risk of bias). J Clin Epidemiol. 2011;64(4):407-15. https://doi.org/10.1016/j. jclinepi.2010.07.017

15. Guyatt GH, Oxman AD, Kunz R, Woodcock J, Brozek J, Helfand $M$, et al. GRADE guidelines: 7. Rating the quality of evidence -- inconsistency. J Clin Epidemiol. 2011;64(12):1294-302. https://doi.org/10.1016/j.jclinepi.2011.03.017

16. Guyatt GH, Oxman AD, Kunz R, Brozek J, Alonso-Coello P, Rind $D$, et al. GRADE guidelines 6 . Rating the quality of evidence -- imprecision. J Clin Epidemiol. 2011;64(12):1283-93. https:// doi.org/10.1016/j.jclinepi.2011.01.012

17. Guyatt GH, Oxman AD, Kunz R, Woodcock J, Brozek J, Helfand $M$, et al. GRADE guidelines: 8 . Rating the quality of evidence -- indirectness. J Clin Epidemiol. 2011;64(12):1303-10. https:// doi.org/10.1016/j.jclinepi.2011.04.014 
18. Lim BS, Leung JW, Lee J, Yen D, Beckett L, Tancredi D, et al. Effect of ERCP mechanical simulator (EMS) practice on trainees' ERCP performance in the early learning period: US multicenter randomized controlled trial. Am J Gastroenterol. 2011;106(2):300-6. https://doi.org/10.1038/ajg.2010.411

19. Liao WC, Leung JW, Wang HP, Chang WH, Chu CH, Lin JT, et al. Coached practice using ERCP mechanical simulator improves trainees' ERCP performance: a randomized controlled trial. Endoscopy. 2013;45(10):799-805. https:// doi.org/10.1055/s-0033-1344224

20. Hritz I, Dubravcsik Z, Szepes AZ, Szepes ZG, Kruglikova I, Jensen $P F$, et al. Assessment of the effectiveness of ERCP mechanical simulator (EMS) exercise on trainees' ERCP performance in the initial learning period: multicenter randomized controlled trial. United European Gastroenterology Journal. 2013;1(1 Supplement 1):A333.

21. Meng $W$, Leung JW, Yue $P$, Wang $Z$, Wang $X$, Wang $H$, et al. Impact of simulation practice on clinical ERCP performance of novice endoscopists - a RCT using ERCP mechanical simulator (EMS). Gastrointestinal Endoscopy. 2019;89(6 Suppl.):AB255-6. https://doi.org/10.1016/j.gie.2019.03.280
22. Meng W, Leung JW, Yue $P$, Wang Z, Wang $X$, Wang $H$, et al. Practice with ERCP mechanical simulator (EMS) improves basic ERCP skills of novice surgical trainees. Gastrointestinal Endoscopy. 2016;83(5 Suppl.):AB267-8. https://doi. org/10.1016/j.gie.2016.03.397

23. D'Assunção MA, Fry LC, Monkemuller K. Development and testing of a new, simple and inexpensive ex-vivo, ERCP training model for basic and intermediate ERCP skills. Gastrointestinal Endoscopy. 2016;83(5 Suppl.):AB608. https://doi.org/10.1016/j. gie.2016.03.1268

24. Hashiba K, Armellini ST, Leite GD, Marson FP, Siqueira PR, Ratin RF, et al. Evaluation of a new model for ERCP training. Gastrointestinal Endoscopy. 2017;85(5 Suppl.):AB220-1. https://doi.org/10.1016/j.gie.2017.03.491

25. Ekkelenkamp VE, Koch AD, de Man RA, Kuipers EJ. Training and competence assessment in GI endoscopy: a systematic review. Gut. 2016;65(4):607-15. https://doi.org/10.1136/ gutjnl-2014-307173

26. Schünemann $H$, Brożek J, Guyatt G, Oxman A. GRADE Handbook, 2013. Available from: https://gdt.gradepro.org/ app/handbook/handbook.html 